\title{
SZABADDUGATTYÚS STIRLING MOTORRAL ÜZEMELŐ LINEÁRIS ALTERNÁTOR FEJLESZTÉSE ÉS MEGVALÓSÍTÁSA
}

\section{DESIGN AND DEVELOPEMENT OF A LINEAR ALTERNATOR FOR FREE PISTON STIRLING ENGINE}

\author{
Máriás Nimród \\ SC ARIADNE IMPEX SRL 520077 Sfântu Gheorghe, jud. Covasna, STR. Lt. Păiș \\ David, Nr.12A,mariasnimrod@yahoo.com
}

\begin{abstract}
The linear alternator is the energie transformer system of the freepiston stirlingengine. The linear motion is generating electricity. However, the alternator has an electric motor operating mode, which is required to start the Stirling engine. The linear alternator is within the Stirling engine pressure wessel, therefore the helium as working gas is well sealed.
\end{abstract}

Keywords: Linear alternator, Free piston Stirling engine, magnet-spring, environmental friendly energy source.

\section{Összefoglalás}

A lineáris alternátor a szabaddugattyús Stirling motorok energia átalakító rendszere, mely vonal menti mozgásból villamos energiát állít elö. Ugyanakkor az alternátor motoros üzemmódban is müködik, mely a Stirling motor indításához szükséges. A lineáris alternátor a Stirling motor nyomásköpenyén belül helyezkedik el, így elérhető a motor hélium munkagázának jó szigetelése.

Kulcsszavak: Lineáris alternátor, Szabaddugattyús Stirling motor, mágnes-rugó, környezetbarát energiaforrás.

\section{Szabaddugattyús Stirling motor- ra épített lineáris alternátor}

Az energiaigényes jelenben egyre jobban kezdenek elterjedni a megújuló energiaforrásokat hasznosító berendezések. Az egyik ilyen energiaforrás a Nap, melynek energiája széles spektrumú elektromágneses sugárzás formájában érkezik a Földre. Napjaink legjobb energia átalakító berendezése a Stirling motoros generátor, mely höenergiát képes átalakítani villamos energiává. A Stirling motorra paraboloid tükrös koncentrátoron keresztül érkezik a Nap höje, mely a Stirling motort müködésre készteti. A Stirling motor pedig egy generátor által villamos áramot szolgáltat. Egy ilyen naperőmü megépítését 2015-ben a XX. FMTÜ alkalmával mutattam be. A lineáris alternátorral ellátott Stirling motor erre a naperőmüre épül, ugyanakkor a megalkotott Stirling energia átalakító a rakéta típusú kályhákban is fel lesz használva. A lineáris alternátor tervet a sepsiszentgyörgyi SC ARIADNE IMPEX mühelyén belül valósítottam meg id. Pózna Dávid igazgató úr támogatásával.

\section{A lineáris alternátor}

A lineáris alternátor szabaddugattyús Stirling motorok energia átalakító rendszere. A Stirling motor nyomásköpenyén belül 
helyezkedik el, hogy biztosítva legyen a motor nagynyomású hélium munkagázának a szivárgás mentessége.

A felépítés miatt, a beindításhoz szükséges mechanikus beavatkozást csak elektromos árammal tudjuk gyakorolni a motorra, mely az alternátoron keresztül kell megtörténjen.

Ezért az alternátor két üzemmódja szükséges: generátoros és motoros üzemmód.

\subsection{A lineáris alternátor tervezési kö- vetelményei}

A lineáris alternátor tervezésénél több szempontot is figyelembe kellett vegyek:

- Olyan berendezés tervezése és megépítése, mely egyszerü felépítése következtében könnyen és olcsón megépíthető és hosszútávú beavatkozás mentes müködést biztosít;

- Az alternátort úgy kell megtervezni, hogy az optimális mozgórész amplitúdó akkora legyen, mint a munkadugattyú amplitúdója. Ez azért szükséges, mert a szabaddugattyús Stirling motorok munkadugattyújáról közvetlenül kerül át a vonal menti mozgás a lineáris alternátor mozgó-részére. Így csökkenthető a súrlódási veszteség;

- $50 \mathrm{~Hz}$ üzemfrekvenciára optimizált alternátor. A szabaddugattyús Stirling motorok üzem-frekvenciája 40 és $60 \mathrm{~Hz}$ között helyezkedik el;

- Az alternátor motoros üzemmódban be kell tudjon indítani egy 40 bar héliummal feltöltött 500W-os Stirling motort.

\subsection{A lineáris alternátor felépítése}

Villamos gépek müködése a mágneses terek kölcsönhatásain alapszik. A gép két részből tevődik össze: mozgórész és állórész.

A lineáris alternátor permanens mágnesekből, és tekercsböl épül fel. Az egyszerübb felépítés végett mozgó mágneses alternátort terveztem. A mozgó mágnesek hatására az állórész vasmagjában fluxus változás lép fel, mely a tekercsben áramot indukál. Célszerü az állórészt tekercselni, mert így nem szükséges hajlékony kivezetéseket beépíteni a rendszerbe. A hajlékony kivezetések idővel elfáradnának, csökkentve az alternátor élettartamát.

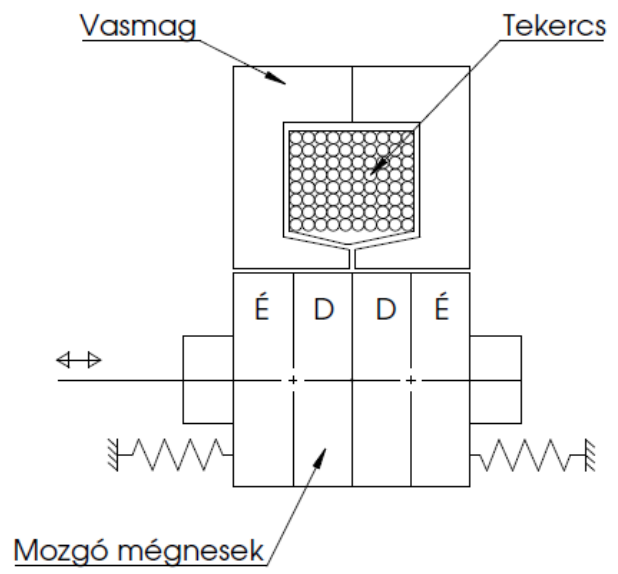

1. ábra. A lineáris alternátor egyszerüsitett metszet

Az alternátor egyszerüsége végett egyetlen tekercset terveztem a rendszerbe, melyet körülölel a lemezelt vasmag. A mozgórészt a tengelyre erősített planár rugók középállásban kell tartsák. A planár rugók előnye, hogy sokkal rövidebb a lineáris alternátor, és egyszerre végzik a rugós tag feladatát és a lineáris megvezető-csapágyak feladatát. A jó mágneses hatásfok érdekében a mozgórész és az állórész közti légrést minimálisra kellett tervezzem. A megépített változatban a légrés $0,5 \mathrm{~mm}$.

$\mathrm{Az}$ elképzelt atlernátor egyszerüsített rajza az 1. ábrán vizsgálható meg.

1. táblázat Felhasználható mágnestípusok

\begin{tabular}{|c|c|c|c|c|}
\hline Típus & $\begin{array}{c}\text { Fluxus- } \\
\text { sủrüség } \\
\mathrm{Br}[\mathrm{mT}]\end{array}$ & $\begin{array}{c}\text { Koercití } \\
\text { v erő } \\
\mathrm{Hcj} \\
{[\mathrm{kOe}]}\end{array}$ & $\begin{array}{c}\text { Ener- } \\
\text { gia } \\
\mathrm{kJ} / \mathrm{m}^{3}\end{array}$ & $\begin{array}{c}\mathrm{T} \\
{ }^{\circ} \mathrm{C}\end{array}$ \\
\hline $\mathrm{N} 42$ & 1280 & $\geq 11,5$ & 318 & 80 \\
\hline $\mathrm{N} 45$ & 1320 & $\geq 11,6$ & 342 & 80 \\
\hline $\mathrm{N} 48$ & 1380 & $\geq 11,6$ & 366 & 80 \\
\hline $\begin{array}{c}\text { SmCo } \\
\text { YX24 }\end{array}$ & 960 & 9,7 & 175 & $\begin{array}{c}20 \\
0\end{array}$ \\
\hline
\end{tabular}


A mozgórészt a tengelyre erősített két darab Neodímium-mágnes alkotja, melyek tengely menti mozgást végeznek. A mágnesek gyürü alakúak.

A választás egy $50 \mathrm{~mm}$ külső átmérőjü, $20 \mathrm{~mm}$ belső átmérőjü és $13,3 \mathrm{~mm}$ vastagságu neodímium mágnesgyürüre esett. A mágnes anyaga $\mathrm{N} 48$, amely $80^{\circ} \mathrm{C}$ fokon még megtartja az elöírt mágneses tulajdonságait. A remanens fluxussürüség N48 esetén $1400 \mathrm{mT}$.

A mozgórész körül a tengelyirányban lemezelt állórész vasmagja és tekercse helyezkedik el.

Az alternátor főbb méreteit az alábbi (1) képlet segítségével határoztam meg:

$$
\begin{gathered}
P=\left(4.8 \cdot 10^{3}\right) \cdot(\tau \cdot D \cdot f \cdot l m) \cdot B_{r}^{2} \cdot \frac{V}{E} . \\
\left\{1-\frac{1}{V}\right\}^{\frac{1}{2}} \cdot \frac{l m}{l m+g} \cdot \frac{f_{1}}{\frac{1-S_{0}}{2} \cdot C_{f}}
\end{gathered}
$$

ahol:

P légrés teljesítmény,

D vasmag belső átmérője,

1 löket legnagyobb amplítudója,

lm mágnes vastagság,

g légrés sugárirányú mérete,

$\mathrm{Br}$ a mágnes fluxussürüség,

$\frac{V}{E} \quad$ a megengedett és a gerjesztett feszültség aránya,

E az indukált feszültség RMS értéke,

$\mathrm{E}_{0} \quad$ Légrés nélkül indukált feszültség RMS értéke.

\section{A lineáris alternátor megvalósí- tása}

Az alternátor megvalósítása 2016. február 09. kezdődött. A tervek elkészítése két hét alatt történt. Az alternátor tervezésénél két szabadalmaztatott forrást használtam, melyek szabaddugattyús Stirling generátorok [1] és lineáris alternátor tervezését és megépítését közlik [2].

Ezután az alkatrészek legyártása kezdődött meg. A vasmag lemezeit egy AMADA
LCG3015AJ lézervágón gyártottam le. A vasmag $1 \mathrm{~mm}$ vastagságú acéllemezből készült. Darabszámuk 364. Az állórész tekercseit $1,5 \mathrm{~mm}$ lakkozott rézhuzalból készítettem el, melynek menetszáma 92. A tekercset poliészter gyantával itattam át a jó villamos szigetelés és a mechanikai ellenállóság érdekében.



\section{2. ábra. A lineáris alternátor testmodellje}

Egy ilyen alternátor megépítésében a legigényesebb szerelés a vasmag lemezeinek a beszerelése a vasmagtartóba. Ezeket a darabokat egyenként be kell helyezni a tartóba, ügyelve arra, hogy a két fedőlaptól galvanikusan el legyenek szigetelve. Az állórész vasmagjait csillag alakban szereltem össze, melyek két oldalról burkolják a tekercset. A kialakított vasmag feleket poliészter gyantával töltöttem fel, mely megnövelte a vasmag szilárdságát. A megszilárdulás után a vasmagok belő átmérőjét csíszológépen munkáltam meg.

A csíszolással állítható be a mágneses légrés mérete. A légrés mérete jelentősen befolyásolja az alternátor.

Az mozgórész két 50 mm átmérőjü gyürü alakú Neodímium mágnesből készült el. A mágnesezési irány tengely menti. Szükséges volt a pólusirányítók használata, mely visszafordítja a pólusokat a mágnesek oldalára. A mágnesek egy $14 \mathrm{~mm}$ átmérőjü csiszolt acéltengelyen helyezkednek el azonos pólussal szembefordítva. Két oldalról egyegy szorítógyürü tartja össze a két gyürü mágnest, melyek egymást $820 \mathrm{~N}$-al taszítják. 
A szorítógyürükre két planár rugó illeszkedik csavarkötéssel.

A planár rugók feladata, hogy a mozgórészt nyugalmi helyzetben tengelyirányban középállásban tartsák.

A planár rugókat $2 \mathrm{~mm}$ vastag rugóacélból gyártottam le a lézervágón galaxis spirál alakúra.

A mozgórész kialakításának köszönhetően a lineáris alternátor amplitúdója $20 \mathrm{~mm}$ lett. Így felhasználható egy szabaddugattyús Stirling motor alternátoraként.

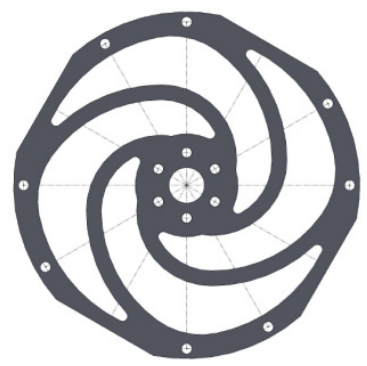

2. ábra Planár rugó testmodellje

A lineáris alternátor jelleggörbéinek a meghatározására egy bütykös tengellyel ellátott villamos motort használok, mely a forgó mozgást 20mm amplitúdójú egyenes vonalú mozgássá alakítja. Az így kialakított kísérleti berendezéssel vizsgálni tudom, hogy $50 \mathrm{~Hz}$ mozgási frekvencián mekkora áramot tud generálni az alternátor. Továbbá meghatározható az alternátor optimális terhelhetösége.
A motoros üzemmód vizsgálatára egy generátort használok, melyet szintén bütykös tengellyel illesztek az alternátorhoz. A generátor terhelését változtatva meghatározható a megépített alternátor optimális terhelhetôsége.

A kutatás még folyamatban ban.

\section{Következtetések}

A planár rugók a spirális rész rövid mérete miatt eléggé merevek lettek. Ezért kis (200W) teljesítményü Stirling motorok alternátoraként csak kis löket mellett ajánlott. A V2 alternátor szerkezetében hoszszabb spirálkarral rendelkező planár rugókat fogok alkalmazni.

Érdemes az alternátorban található planár rugókat mágneses rugókra lecserélni. A mágneses rugók élettartama hosszabb a planár rugókhoz képest. Egy ilyen változatnál figyelembe kell venni, hogy a mágnesek közti erő a távolság függvényében négyzetesen változik.

\section{Szakirodalmi hivatkozások}

[1] George R. Dochat, DOE/NASA/0056-79/1 NASA CR-1 59587 MTI 79TR47 Design Study of a $15 \mathrm{~kW}$ Free-piston Stirling Enginelinear Alternator for Dispersed Solar Electric Power

[2] U.S. Department of energy, ORNL/Sub/8405907/1 Preliminary Design of Linear Alternator Dynamometer for Free Piston Stirling Engines 